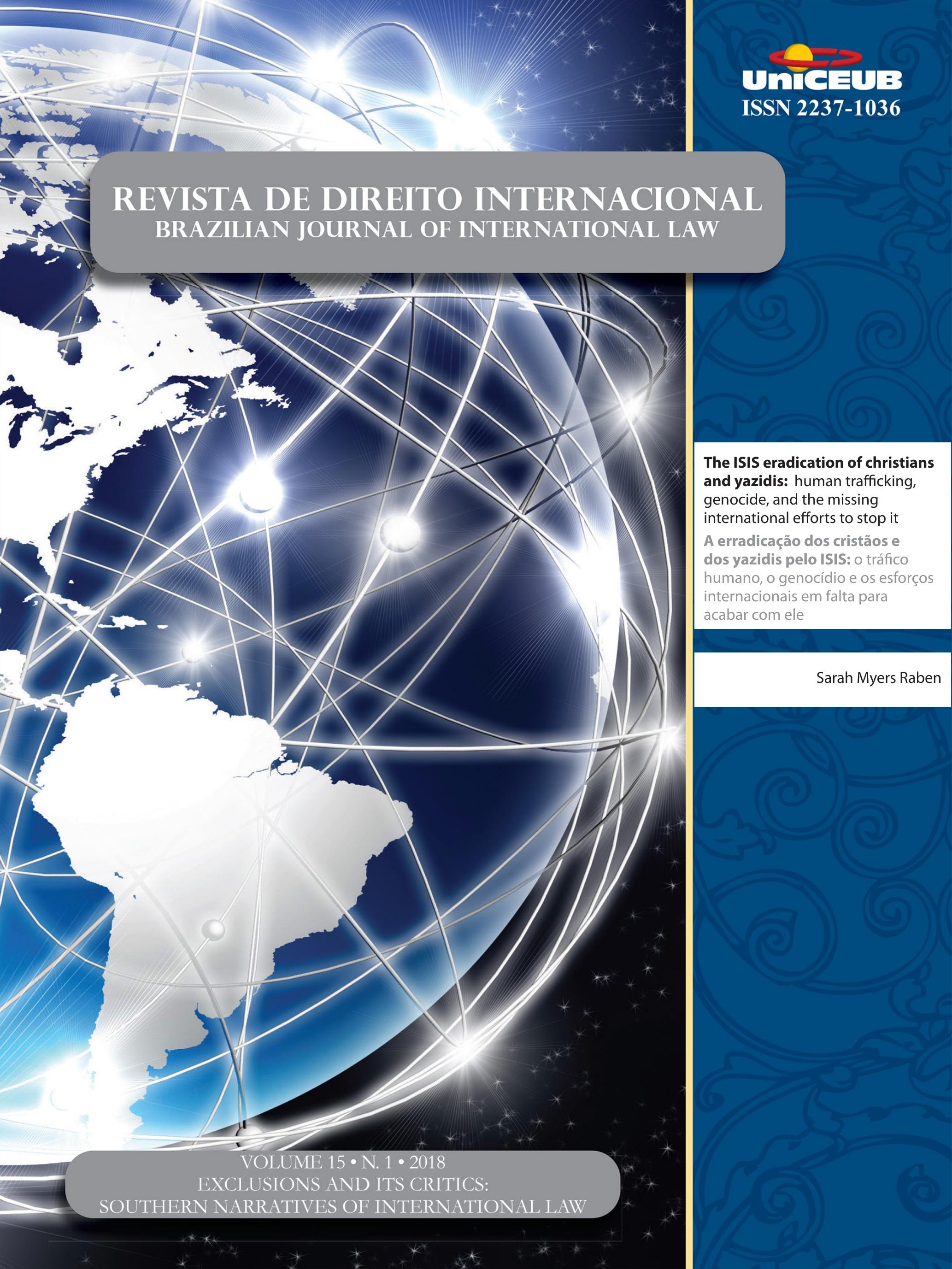




\section{Sumário}

I. Dossiê Especial: Exclusions and its Critics: Southern Narratives of

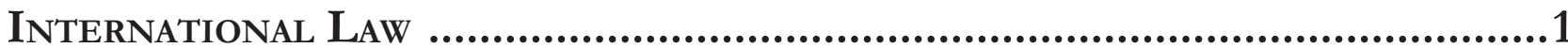

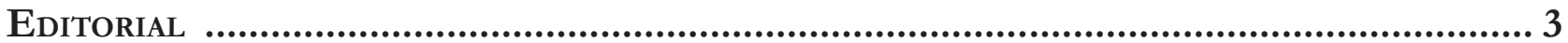

Conseguimos pensar em narrativas críticas do Direito Internacional no Sul Global? ......................... 3

ENTRE A APOLOGIA E A UTOPIA: A POLÍTICA Do DIREITO INTERNACIONAL................................ 6 Martti Koskenniemi e Tradutor João Roriz

A POLÍTICA Do DIREITO INTERNACIONAL: 20 ANOS DEPOIS ...................................................31 Martti Koskenniemi e Tradutor João Roriz

Abordagens terceiro-mundistas para o Direito Internacional: Um Manifesto............42 Bhupinder S. Chimni

Around the pyramid: Political-theoretical challenges to law in the age of global GOVERNANCE

Salem Hikmat Nasser e José Garcez Ghirardi

VOICE AND EXIT: HOW EMERGING POWERS ARE PROMOTING INSTITUTIONAL CHANGES IN THE INTERNATIONAL MONETARY SYSTEM

Camila Villard Duran

LA LIBRE AUTODETERMINACIÓN DE LOS PUEBLOS EN EL SIGLO XXI: UNA APROXIMACIÓN DE LA HISTORIA DEL COLONIALISMO Y EL NEO-COLONIALISMO DESDE LOS PUEBLOS DEL TERCER MUNDO

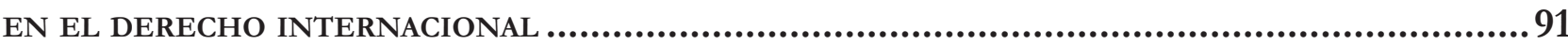

Germán Medardo Sandoval Trigo

INTERNATIONAL CLIMATE CHANGE REGIME AS A PROMOTER OF COLONIAL SYSTEMIC AND SYMBOLIC VIOLENCE: ITS RELATIONSHIP WITH INTERNATIONAL ENVIRONMENT SECURITY AND FOOD SYSTEM THRU THE LENS OF FEMINIST APPROACH 106

Douglas Castro e Bruno Pegorari 
Jus COGENS: AN EUROPEAN CONCEPT? AN EMANCIPATORY CONCEPTUAL REVIEW FROM THE INTER-AMERICAN SYSTEM OF HUMAN RIGHTS

Tatiana de A. F. R. Cardoso Squeff e Marina de Almeida Rosa

O CONHECIMENTO TRADICIONAL RELACIONADO AO COMPLEXO DO CURARE E A LEGISLAÇÃO IN-

TERNACIONAL SOBRE PROPRIEDADE INTELECTUAL. 139

Marcos Vinício Chein Feres e João Vitor de Freitas Moreira

II. Artigos sobre outros temas

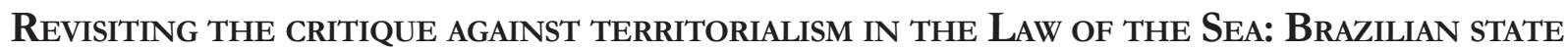
PRACTICE IN LIGHT OF THE CONCEPTS OF CREEPING JURISDICTION AND SPOLIATIVE JURISDICTION ..161 Victor Alencar Mayer Feitosa Ventura

EDUCAÇÃO SUPERIOR INTERCULTURAL, RECONHECIMENTO E REDISTRIBUIÇÃO: O DURO CAMINHO DOS POVOS INDÍGENAS NO EQUADOR 180

Vanessa Wendhausen Cavallazzi, Patrícia Perrone Campos Mello e Raony Soares

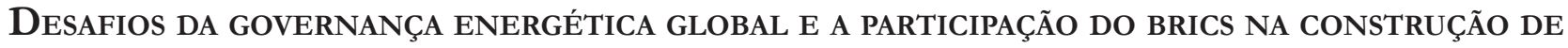
UM NOVO PARADIGMA ENERGÉTICO 200

Fernanda Volpon e Marilda Rosado de Sá Ribeiro

A hermeneutical analysis on the recognition of China as a market economy after 2016.

Alberto Amaral Júnior e Aline Pereira de Carvalho Heringer

THE ISIS ERADICATION OF CHRISTIANS AND YAZIDIS: HUMAN TRAFFICKING, GENOCIDE, AND THE MISSING INTERNATIONAL EFFORTS TO STOP IT

Sarah Myers Raben

The strategic prudence of The Inter-American Court of Human Rights: Rejection OF REQUESTS FOR AN ADVISORY OPINION 255

Cecilia M. Bailliet

Direito Internacional Monocromático: PREVISÃo e apliCaÇÃo dos Direitos LGBTI NA ORDEM INTERNACIONAL 278

Rafael Carrano Lelis e Gabriel Coutinho Galil 
III. RESENHAS

Resenha do livro Empire de Michael Hardt e Antonio Negri 301 Arthur Roberto Capella Giannattasio

Resenha do livro Imperialism, Sovereignty and the Making of International LaW, de

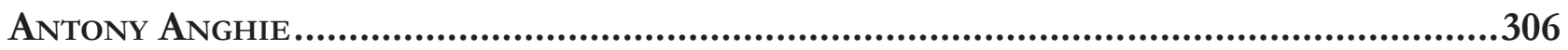

Fabrício José Rodrigues de Lemos e Laura Madrid Sartoretto 


\title{
The ISIS eradication of christians and yazidis: human trafficking, genocide, and the missing international efforts to stop it*
}

\author{
A erradicação dos cristãos e dos yazidis \\ pelo ISIS: o tráfico humano, o genocídio e os \\ esforços internacionais em falta para acabar \\ com ele
}

Sarah Myers Raben**

\begin{abstract}
Human trafficking is one of the most shocking and horrifying crimes of the twenty-first century-a criminal enterprise that is funding and motivating terrorist groups like ISIS. The systematic brutality against Christians and Yazidis is unparallel, as ISIS battles to exterminate any trace of non-Muslim groups from Syria and Iraq. Pope Francis brought ISIS atrocities onto the world stage and called it genocide, as did U.S. Secretary of State John Kerry. While the United Nations acknowledged genocide against the Yazidis, the U.N. erred when it failed to distinguish the violence against Christians as genocide, as well. ISIS forces are on the decline, but accountability for their crimes is inconclusive. Iraq and Syria are not members of the International Criminal Court, which means ISIS fighters are unlikely to be subject to jurisdiction of any ICC proceeding. While the number of nations enacting trafficking statutes continues to increase, the laws are virtually powerless unless ISIS criminals are inside the borders of the country. The only plausible avenue lies in the U.N. Security Council resolution to investigate ISIS war crimes in Iraq. While U.S.-backed forces continue to weaken ISIS, the world stage should proceed with careful optimism, and not let Christianity be an impediment to a strong stance against terrorism.
\end{abstract}

Keywords: ISIS. Genocide. Yazidis. Christians. Human Trafficking.

* Recebido em: 02/04/2018

Aprovado em: 02/04/2018

** Juris Doctorate candidate at the University of Mississippi School of Law (2018), and a Staff Editor of the Mississippi Law Journal. The author would like to thank her faculty advisor Professor Ronald Rychlak for his confidence, knowledge, and direction, as well as Professor John Czarnetzky for his assistance and encouragement. She would also like to thank her bonus dad Keith Sorrell for his countless hours of legal explanations, her mother, and her husband and their three daughters for their unwavering support and patience. Email: smraben@go.olemiss.edu.

\section{Resumo}

O tráfico humano é um dos crimes mais chocantes e horríveis do século XXI - um empreendimento criminoso que financia e motiva grupos terroristas como o ISIS. A brutalidade sistemática contra os cristãos e os yazidis é inigualável, enquanto o ISIS luta para exterminar qualquer vestígio de grupos não-muçulmanos da Síria e do Iraque. O Papa Francisco trouxe as atrocidades do ISIS para o cenário mundial e o chamou de genocídio, assim como o secretário de Estado dos EUA, John Kerry. Enquanto as Nações Unidas reconheceram o genocídio contra os yazidis, também erraram ao não conseguir distinguir a violência contra cristãos como genocídio. As forças do ISIS estão em declínio, mas a responsabilidade por seus crimes é inconclusiva. O Iraque e a Síria não são membros do Tribunal Penal Internacional, o que significa que os combatentes do ISIS não estão sujeitos à jurisdição de qualquer processo do TPI. Enquanto o número de nações que 
promulga leis contra o tráfico continua a aumentar, elas são virtualmente impotentes, a menos que criminosos do EI estejam dentro das fronteiras do país. A única via plausível está na resolução do Conselho de Segurança da ONU para investigar os crimes de guerra do Estado Islâmico no Iraque. Embora as forças apoiadas pelos EUA continuem a enfraquecer o ISIS, o cenário mundial deve prosseguir com um otimismo cuidadoso, e não deixar o cristianismo ser um impedimento para uma postura forte contra o terrorismo.

Palavras-chave: ISIS, genocídio, yazidis, cristiãos, tráfico humano

\section{INTRODUCTION}

Human trafficking is one of the most tragic human rights issues of our time. It splinters families, distorts global markets, undermines the rule of law, and spurs other transnational criminal activity. It threatens public safety and national security. But worst of all, the crime robs human beings of their freedom and their dignity. That's why we must pursue an end to the scourge of human trafficking ${ }^{1}$

Modern day slavery is more prevalent now in the twenty-first century than ever before, with twenty-seven million men, women, and children imprisoned or controlled across the globe. ${ }^{2}$ Human trafficking generates an estimated $\$ 32$ billion annually, ${ }^{3}$ making it the second

1 Rex W. Tillerson, Secretary of State, Letter from Secretary Tillerson, Trafficking in Persons Report 2017. Available in: https://www.state. gov/j/tip/rls/tiprpt/2017/271105.htm.

2 Andrew Cockburn, 21st-Century Slaves, National Geographic, (Sept. 2003). "[T] here are more slaves today than were seized from Africa in four centuries of the trans-Atlantic slave trade [11 million total, and about 450,000 , or about $4 \%$ of the total, who were brought to the United States]. The modern commerce in humans rivals illegal drug trafficking in its global reach-and in the destruction of lives." Mark J. Perry, Thomas Sowell on Slavery and This Fact -There are More Slaves Today Than Were Seized From Africa in Four Centuries, AEIdeas (October 18, 2017). Available in: http://www.aei. org/publication/thomas-sowell-on-slavery-and-this-fact-there-aremore-slaves-today-than-were-seized-from-africa-in-four-centuries/. 3 Melissa L. Breger, Trauma in Sex-Trafficked Children, in Human Trafficking, Emerging Legal Issues and Applications, 171, 172 (Nora M. Cronin \& Kimberly A. Ellis eds., 2017). See also End Trafficking, UNICEF. Available in: http s://www.unicefusa.org/sites/default/ files/assets/pdf/End-Child-Trafficking-One-Pager.pdf. (last visited Dec. 7, 2017). See generally Loretta Napoleoni, Merchants of Men: How Jihadists and ISIS Turned Kidnapping and Refugee Trafficking into a Multi-Billion Dollar Business (2016). This book follows the largest criminal enterprise, only surpassed by drugs. ${ }^{4}$ The Islamic State (ISIS) ${ }^{5}$ is raging a war against Christians, Yazidis, and every other group not aligning with its religious beliefs, trying to eradicate any "infidels" not aligned with the Prophet Muhammad's religious teachings. ${ }^{6}$ ISIS fighters and leaders exploit the families in the villages they capture and sell women and children as sex slaves or systematically rape them into submission. ${ }^{7}$ ISIS fighters instill horrific fear by beheading their hostages as a tool to convert non-believers. ${ }^{8}$ Complicating the issue is the low social status of women in many parts of the world, which only contributes to the "burgeoning of the trafficking industry." Recent months are producing aggressive attacks aimed at ISIS, and a reclaiming of key Middle Eastern cities. ${ }^{10}$ However, the

money trail and traces how jihadi groups are making record profits from the current refugee crisis.

4 Nick Vivion, Human Trafficking: Toppling a \$32 Billion Illegal Industry through Tecbnology, Sabre (May 25, 2016). Available in: https:// www.sabre.com/insights/human-trafficking-toppling-a-32-billion-illegal-industry-through-technology/. See also End Trafficking, UNICEF. Available in: https://www.unicefusa.org/sites/default/ files/assets/pdf/End-Child-Trafficking-One-Pager.pdf.

5 IS, ISIL, and ISIS are all names used to identify the jihadist group that controls areas in Iraq and Syria. IS is an abbreviation for Islamic State, ISIL is the acronym for Islamic State in Iraq and the Levant, and ISIS comes from the names Islamic State in Iraq and Syria and Islamic State in Iraq and al-Sham. Daesh is a named used more commonly in the Arabic-speaking world where acronyms are uncommon. Faisal Irshaid, Isis, Isil, IS or Daesh? One Group, Many Names, BBC (Dec, 2, 2015). Available in: http://www.bbc.com/ news/world-middle-east-27994277.

6 Nina Shea, ISIS Genocide of Christian Communities in Iraq and Syria, in The Persecution and Genocide of Christians in the Middle East 17, 21-22 (Ronald J. Rychlak \& Jane F. Adolphe eds., 2017).

7 Trafficking and Terrorism, Partners in Crime, The Freedom Story (June 29, 2017). Available in: http://thefreedomstory.org/ trafficking-and-terrorism-partners-in-crime. See also Terrorists use Human Trafficking to Generate Revenue, Demoralize Adversaries, Fill the Ranks, Lexis-Nexus (Dec. 31, 2014). Available in: http:// www.homelandsecuritynewswire.com/dr20141231-terrorists-usehuman-trafficking-to-generate-revenue-demoralize-adversaries-fillthe-ranks.

8 Trafficking and Terrorism, Partners in Crime, The Freedom Story (June 29, 2017). Available in: http://thefreedomstory.org/ trafficking-and-terrorism-partners-in-crime. See also Terrorists use Human Trafficking to Generate Revenue, Demoralize Adversaries, Fill the Ranks, Lexis-Nexus (Dec. 31, 2014). Available in: http:// www.homelandsecuritynewswire.com/dr20141231-terrorists-usehuman-trafficking-to-generate-revenue-demoralize-adversaries-fillthe-ranks.

9 Victims of Trafficking and Violence Protection Act of 2000, H.R. 3244, 106th Cong. \ 102(2) (2000). https://www.state.gov/j/ tip/laws/61124.htm (October 28, 2000).

10 Hilary Clarke, Nick Paton Walsh, Eliza Mackintosh \& Ghazi Balkiz, ISIS Defeated in Raqqa as 'Major Military Operations' Declared Over, CNN (Oct. 18, 2917). Available in: http://www.cnn. 
threat of ISIS and its terror are as present as ever. The business of human trafficking is flourishing ${ }^{11}$ and ISIS continues to threaten Christians in the Western World. ${ }^{12}$ Yet the United Nations (U.N.) fails to acknowledge the brutality and intent aimed at Christians, even though the acts coincide and are indistinguishable from the brutality and horror against the Yazidis.

Human trafficking legislation in the United States continues to evolve, but the laws are reactive, and only as effective as the ability to capture terrorists. Further, they have little if any impact on the ISIS genocide in the Middle East. The U.N. also has policies and international laws criminalizing the "genocide" $" 13$ of religious

com/2017/10/17/middleeast/raqqa-isis-syria/index.html.

11 Nima Elbagir, Ghazi Balkiz, \& Tamara Qiblawi, ISIS' Power is Waning, but its Child Slave Trade is Still Booming, CNN (Oct. 18, 2017). Available in: http://www.cnn.com/2017/10/18/middleeast/isisyazidi-slavery-child-slaves/index.html.

12 Pope Francis, Christianity Threatened in ISIS Propaganda Video that Vatican Aide Calls Worrying, Fox News (Aug. 26, 2017). Available in: http://www.foxnews.com/world/2017/08/26/pope-francis-christianity-threatened-in-isis-propaganda-video.html.

13 See generally Nina Shea, ISIS Genocide of Christian Communities in Iraq and Syria, in The Persecution and Genocide of Christians in the Middle East 17 (Ronald J. Rychlak \& Jane F. Adolphe eds., 2017).

Article II - In the present Convention, genocide means any of the following acts committed with intent to destroy, in whole or in part, a national, ethnical, racial or religious group, as such:

a. Killing members of the group;

b. Causing serious bodily or mental harm to members of the group;

c. Deliberately inflicting on the group conditions of life calculated to bring about its physical destruction in whole or in part;

d. Imposing measures intended to prevent births within the group; (e) [sic] Forcibly transferring children of the group to another group.

Elements of the crime

The Genocide Convention establishes in Article I that the crime of genocide may take place in the context of an armed conflict, international or non-international, but also in the context of a peaceful situation. The latter is less common but still possible. The same article establishes the obligation of the contracting parties to prevent and to punish the crime of genocide.

The popular understanding of what constitutes genocide tends to be broader than the content of the norm under international law. Article II of the Genocide Convention contains a narrow definition of the crime of genocide, which includes two main elements:

1. A mental element: the "intent to destroy, in whole or in part, a national, ethnical, racial or religious group, as such"; and

2. A physical element, which includes the following five acts, enumerated exhaustively:

Killing members of the group,

Causing serious bodily or mental harm to members of the group,

Deliberately inflicting on the group conditions of life calculated to bring about its physical destruction in whole or in part,

Imposing measures intended to prevent births within the group, Forcibly transferring children of the group to another group.

The intent is the most difficult element to determine. To consti- targets, but efforts are still not substantial enough to subdue violent instability in the Middle East. While the U.N. acknowledges the methodical attacks against the Yazidis as genocide, there remains a reluctance to assert the same designation in regards to Christians, despite repeated and vivid proclamations from ISIS.

Part I of this Article will briefly review the development of ISIS and the historical events that led to current leadership. Part II will identify the specific acts of terror and trafficking of ISIS as part of the group's mission to exterminate Christians and Yazidis. Part III will address the U.N.'s failure to identify the brutality of ISIS towards Christians as genocide, and analyze why the acts warrant the declaration. Finally, Part IV will evaluate the legal options available under international policies and laws, and the importance of individual nations enacting statutes that criminalize trafficking.

\section{THE FORMATION OF ISIS}

The terrorism attacks on September 11, 2001, jolted the American people and established al Qaeda as a household name. ${ }^{14}$ The man credited with starting ISIS, Abu Musab al-Zarqawi, split from al Qaeda in Iraq in 2004 to form his own group and within two years waged war on the Shiite community. ${ }^{15}$ In June 2006, a U.S.

tute genocide, there must be a proven intent on the part of perpetrators to physically destroy a national, ethnical, racial or religious group. Cultural destruction does not suffice, nor does an intention to simply disperse a group. It is this special intent, or dolus specialis, what makes the crime of genocide so unique. In addition, case law has associated intent with the existence of a State or organizational plan or policy, even if the definition of genocide in international law does not include that element.

Importantly, the victims of genocide are deliberately targeted - not randomly - because of their real or perceived membership of one of the four groups protected under the Convention (which excludes political groups, for example). This means that the target of destruction must be the group, as such, and not its members as individuals. Genocide can also be committed against only a part of the group, as long as that part is identifiable (including within a geographically limited area) and "substantial."

United Nations Genocide Prevention and the Responsibility to Protect, United Nations. Available in: http://www.un.org/en/genocideprevention/genocide.html.

14 "September 11 was an extraordinary crisis, warranting emergency measures of extraordinary scope. But there is, unfortunately, no reason to believe that the threat of terrorism will recede any time soon. More likely, the 'emergency' will be with us through several future presidential administrations." Stephen J. Schulhofer, The Enemy Within 68 (2002).

15 Ray Sanchez, ISIL, ISIS or the Islamic State?, CNN (Oct. 25, 
air strike killed al-Zarqawi, and Abu Ayyub al-Masri succeeded in leadership. ${ }^{16}$ Later that year al-Masri announced the creation of the Islamic State in Iraq (ISI) and named Abu Omar al-Baghdadi as the leader. ${ }^{17}$ In 2010, a joint-operation between the U.S. and Iraq killed both Abu Omar al-Baghdadi and al-Masri; then Abu Bakr al-Baghdadi succeeded in power. ${ }^{18}$ In 2013, ISI absorbed the al Qaeda-backed militant group in Syria and became known as ISIS. ${ }^{19}$ Violence from ISIS increased throughout 2014 and $2015^{20}$ while ISIS expanded its territory in Iraq and Syria and took control of the cities of Fallujah, Mosul, Tikrit, and Al-Qaim. ${ }^{21}$ In February 2015, President Obama asked Congress to authorize the use of force against ISIS. ${ }^{22}$ As of October 2017, U.S. military leaders believed al-Baghdadi was still heading up the ISIS organization. ${ }^{23}$

\section{The ISIS intent to eradicate Christians AND YAZIDIS}

2017). Available in: http://www.cnn.com/2014/09/09/world/ meast/isis-isil-islamic-state/.

16 CNN Library, ISIS Fast Facts, CNN (Updated Oct. 17, 2017). Available in: http://www.cnn.com/2014/08/08/world/isis-fastfacts/index.html.

17 Id.

18 Id.

19 Id.

20 Id. August 19, 2014, ISIS posted a video of the beheading of James Foley, a journalist from the U.S. missing since 2012; September 2, 2014, ISIS posted a video of the beheading of Steven Sotloff, another U.S. journalist; September 13, 2014, ISIS posted a video of the execution of David Haines, a British aid worker; October 3, 2014 ISIS released another video of the beheading of Alan Henning, a British hostage; November 16, 2014 ISIS posted a video of Peter Kassig, a dead American hostage; January 24, 2015, ISIS released pictures of Haruna Yukawa, a Japanese hostage and on January 31, 2015, a video of a second Japanese hostage, Kenji Goto, beheaded; February 3, 2015 ISIS posted pictures and video of Jordanian pilot Moath al-Kasasbeh being burned alive while locked in a cage. $I d$.

21 Id.

22 Letter from President Barack Obama to The Congress of the United States (Feb. 11,2015). Available in: http://i2.cdn.turner. com/cnn/2015/images/02/11/2015aumf.2.11.15.msg.rel.pdf. See also Jim Acosta \& Jeremy Diamond, Obama ISIS Fight Request Sent to Congress, CNN (February 12, 2015). Available in: http://www.cnn. com/2015/02/11/politics/isis-aumf-white-house-congress/index. html.

23 Jack Moore, ISIS Leader Abu Bakr Al-Baghdadi is Likely Alive, U.S. Commander Says, Newsweek (Sept. 1, 2017). Available in: http:// www.newsweek.com/intelligence-points-isis-leader-abu-bakr-albaghdadi-being-alive-us-commander-658192. Rumors surfaced in mid-June 2017 that al-Baghdadi was killed in an airstrike, but U.S. military is skeptical. Id.
In 2014 after ISIS captured the city of Mosul, the group set out to entirely exterminate Christians, Yazidis, and every other religious community in the Province of Nineveh that was non-Muslim. ${ }^{24}$ ISIS leaders gave the Christians an ultimatum - either they could stay and pay a traditional Islamic tax called a jizya, or flee to escape death. ${ }^{25}$

\subsection{The False ISIS Promise of a Jizya and Coexistence with Christians}

In reality, ISIS did not offer the traditional jizya to the Christians. It was nothing more than a false promise used by ISIS "for propaganda purposes and to appear more caliph-like."26 ISIS summoned Christian leaders, who feared the terrorists were attempting to convene all of the Christians in the Mosul auditorium for a slaughter. ${ }^{27}$ At the appointed time to meet, none of the Christians showed, which infuriated ISIS and subsequently triggered threats to the Christians to leave

24 Nina Shea, ISIS Genocide of Christian Communities in Iraq and Syria, in The Persecution and Genocide of Christians in the Middle East 17, 22 (Ronald J. Rychlak \& Jane F. Adolphe eds., 2017). 25 Id. at 23.

26 Hudson Institute Releases Report on the ISIS Propaganda Ploy to Hide its Genocide of Christians, Hudson Institute (July 21, 2016). Available in: https://www.hudson.org/research/12666-hudson-institute-releases-report-on-the-isis-propaganda-ploy-to-hide-its-genocide-ofchristians.

Jizya is mentioned once in the Qur'an (9:29, Surah al-Tawbah), although no payment amount or details are actually given. Under what is known as the Pact of Omar (named after a seventh- century caliph), jizya was an arrangement for coexistence with "People of the Book" ahl al kitab, meaning Jews and Christians, and even Sabean-Mandeans and Zoroastrians. A progressive tax was paid by men or their community in exchange for guarantees for their families: protection of their lives and property and the right to worship, receive the sacraments, and perform their religious rights. They did not have full religious freedom, were harshly discriminated against, and were compelled to adhere to Muslim mores in ways that were deliberately humiliating and onerous and would be seen today as flagrant violations of international human rights law. Yet this arrangement at least allowed the protected non-Muslim communities to assemble inside their houses of worship for communal prayer, led by their own religious leaders. For 1,300 years, from the region's Muslim conquest in the seventh century until the mid-nineteenth, Christianity was practiced and perpetuated in this region under such arrangements.

Nina Shea, The ISIS Genocide of Middle Eastern Christian Minorities and Its Jizya Propaganda Ploy, Hudson Institute (Aug., 2016). Available in: https://s3.amazonaws.com/media.hudson.org/files/publications/20160721TheISISGenocideofMiddleEasternChristianMinoriti esandItsJizyaPropagandaPloy.pdf.

27 Nina Shea, ISIS Genocide of Christian Communities in Iraq and Syria, in The Persecution and Genocide of Christians in the Middle East 17, 28-29 (Ronald J. Rychlak \& Jane F. Adolphe eds., 2017). 
the city or be killed. ${ }^{28}$ Three weeks later, ISIS repeated the same ultimatum throughout the Nineveh Province, which left just a small fraction of Christians in Iraq. ${ }^{29}$

\subsection{The Methodical and Disturbing Capitalization of Women and Children}

ISIS capitalized on the fleeing and fear by capturing the refugees to finance its terrorism and became one of the first organizations to create an open public market for human trafficking. ${ }^{30}$

\begin{abstract}
After attacking a village, [ISIS] splits women from men and executes boys and men aged 14 and over. The women and mothers are separated; girls are stripped naked, tested for virginity and examined for breast size and prettiness. The youngest, and those considered the prettiest virgins fetch higher prices and are sent to Raqqa, the [ISIS] stronghold. There is a hierarchy: sheikhs get first choice, then emirs, then fighters. They often take three or four girls each and keep them for a month or so, until they grow tired of a girl, when she goes back to market. At slave auctions, buyers haggle fiercely, driving down prices by disparaging girls as flatchested or unattractive. ${ }^{31}$
\end{abstract}

"They are institutionalizing sexual violence," said U.N. investigator Zainab Bangura. ${ }^{32}$ "The brutalization of women and girls is central to their ideology." ${ }^{33}$

ISIS did not tolerate Christians. ${ }^{34}$ The group purpor-

$28 \quad I d$.

29 Id. at 28.

30 Shannon A. Welch, Note, Human Trafficking and Terrorism: Utilizing National Security Resources to Prevent Human Trafficking in the Islamic State, 24 Duke J. Gender L. \& Pol'y, 165, 169 (2017).

31 James Reinl, Q\&A: Probing Islamic State's Sex Atrocities with the United Nations, Middle East Eye (May 18, 2015). Available in: http://www.middleeasteye.net/news/qa-probing-islamic-state-ssex-atrocities-united-nations-1064004421. The head of a United Nations envoy Zainab Bangura investigated allegations of mass rape, forced marriages, and slavery in the Middle East. Id. See also Ishaan Tharoor, Islamic State Burned a Woman Alive for not Engaging in an 'Extreme' Sex Act, U.N. Official Says, The Washington Post (May 22, 2015). Available in: https://www.washingtonpost.com/news/ worldviews/wp/2015/05/22/islamic-state-burned-a-woman-alivefor-not-engaging-in-an-extreme-sex-act-u-n-official-says/?utm_ term $=.4058 \mathrm{e} 0 \mathrm{a} 57 \mathrm{e} 79$.

32 James Reinl, QUA: Probing Islamic State's Sex Atrocities with the United Nations, Middle East Eye (May 18, 2015). Available in: http:/ / www.middleeasteye.net/news/qa-probing-islamic-state-s-sex-atrocities-united-nations-1064004421.

33 Id.

34 Nina Shea, The ISIS Genocide of Middle Eastern Christian Minorities and Its Jisya Propaganda Ploy Hudson Institute (Jul. 21, 2016). Available in: https://www.hudson.org/research/12665-the-isisgenocide-of-middle-eastern-christian-minorities-and-its-jizya-prop- ted to demand a jizya to avoid death or deportation, which was actually extortion and ransom. ${ }^{35}$ In reality, ISIS did not give such an option to Christians at any time, and instead turned to murder, kidnapping, or enslaving them. ${ }^{36}$

A Christian mother attested that she was brutally tortured and taken to a slave detention center with other Christian and Yazidi girls. ${ }^{37}$

That night I was married to eight different men
and divorced eight times. Each man raped me three
or four times. When it was all over, we were taken
back to the room where all the girls were being held.
They made us walk naked through the big room
where all the men were sitting. We were barely able
to walk. The scenario was repeated every week-it
was like a nightmare. ${ }^{38}$

ISIS fighters captured and enslaved Leila, a twenty-three year old woman, who they sold to a military commander. ${ }^{39}$ Her captor imprisoned her for more than a year, and regularly raped and tortured her. ${ }^{40}$ She said he did "a lot of terrible things — actions against God." 41

In August of 2014, ISIS attacked the town of Sinjar, Iraq, home to the Yazidis. ${ }^{42}$ More than 50,000 Yazidis fled to Sinjar Mountain, while thousands of others were subjected to systematic killings and rapes. ${ }^{43}$ Emad Tammo, a thirteen-year old Yazidi spent three years as a slave for ISIS, forced to carry ammunition and water. ${ }^{44}$ " $[\mathrm{H}]$ e could barely speak, and his small body looked fragile after only eating small pieces of dates for months." ${ }^{45}$ Emad described many injuries he sustained while enslaved by ISIS; shrapnel from a mortar lacerated his stomach, a bullet hit his elbow, and debris from a blown-

aganda-ploy.

35 James Reinl, Q\&A: Probing Islamic State's Sex Atrocities with the United Nations, Middle East Eye (May 18, 2015). Available in: http:// www.middleeasteye.net/news/qa-probing-islamic-state-s-sex-atrocities-united-nations-1064004421.

36 Id.

37 Nina Shea, ISIS Genocide of Christian Communities in Iraq and Syria, in The Persecution and Genocide of Christians in the Middle East 17, 33 (Ronald J. Rychlak \& Jane F. Adolphe eds., 2017).

38 Id.

39 Cathy Otten, Life After ISIS Slavery for Yazidi Women and Children, The New Yorker (Aug. 31, 2017). Available in: https://www. newyorker.com/news/news-desk/life-after-isis-slavery-for-yazidiwomen-and-children.

$40 \quad I d$.

41 Id.

42 Id.

43 Id.

44 Id.

$45 \quad I d$. 
-apart building hit his head after an air strike. "Some of them were beating and insulting me, and some of them were a little better than others ... [ $[\mathrm{t}$ depended on who I was with." ${ }^{47}$

ISIS members had no desire to cohabitate or live alongside Christians and Yazidis. The fighters systematically tortured, enslaved, and killed anyone not aligned with ISIS, and drove out nearly all existence of Christians and Yazidis in ISIS-controlled areas. ${ }^{48}$

\subsection{ISIS Justification of Rape and Torture with Religion}

These violent, horrific accounts were not challenged or rebuked by ISIS, but instead, touted as religiously sanctioned. In the ISIS English-language digital magazine Dabiq, the terrorist group bragged and celebrated their horrific actions. ${ }^{49}$

Before Shayțān reveals his doubts to the weakminded and weak hearted, one should remember that enslaving the families of the [infidels] and taking their women as concubines is a firmly established aspect of Shari ${ }^{-}$ah that if one were to deny or mock, he would be denying or mocking the verses of the Qur' ān and the narrations of the Prophet $\ldots$ and thereby apostatizing from Islam. ${ }^{50}$

Just over a decade ago, Iraq and Syria had the most "robust Christian populations" in the Middle East. ${ }^{51}$ Collectively, there were 1.4 million people in the Iraqi Christian community in 2003, but church leaders in the last few years estimated only a fraction of them, approximately 250,000 , were left, mostly living as refuges. ${ }^{52}$ Syria previously had two million Christians living inside the country. ${ }^{53}$ As of recent years, between one million

$46 \quad I d$.

$47 \quad I d$.

48 See generally Nina Shea, ISIS Genocide of Christian Communities in Iraq and Syria, in The Persecution and Genocide of Christians in the Middle East 17 (Ronald J. Rychlak \& Jane F. Adolphe eds., 2017).

49 See generally The Revival of Slaver Before the Hour, Dabiq (2014). See also Allen McDuffee, ISIS Is Now Bragging About Enslaving Women and Children, The Atlantic Daily (Oct. 13, 2014). Available in: https://www.theatlantic.com/international/archive/2014/10/ isis-confirms-and-justifies-enslaving-yazidis-in-new-magazine-article/381394/.

50 The Revival of Slaver Before the Hour, Dabiq (2014).

51 Nina Shea, ISIS Genocide of Christian Communities in Iraq and Syria, in The Persecution and Genocide of Christians in the Middle East 17, 20 (Ronald J. Rychlak \& Jane F. Adolphe eds., 2017).

52 Id.

53 Id. at 20-21. and 1.5 million of the country's Christians remained, and two-thirds of them were displaced. ${ }^{54}$

In 2015, Pope Francis brought the terrorist actions of ISIS onto the world stage, and called the actions "genocide," stating, "our brothers and sisters are persecuted, tortured and killed for their faith in Jesus." ${ }^{\prime 5}$ The following March, the U.S. Secretary of State John Kerry agreed and officially declared ISIS responsible for genocide among Christians, Yazidis, and Shiite Muslims in Syria and Iraq. ${ }^{56}$

The terrorist group extinguished nearly two thousand years of religious history and almost every physical trace of Christianity in ISIS-controlled territories. ${ }^{57}$ The assassination of clergy and the destruction of churches started before the emergence of ISIS, but the radical group has almost completely eliminated Christian communities in Syria and Iraq "with brutality that was both deliberate and systematic." 58

The U.N. reaction to ISIS crimes of extreme violence and brutality was disappointing. In 2016, the U.N.-established International Commission of Inquiry on Syria completely failed to acknowledge the persecution of Christians. ${ }^{59}$ While the Yazidis were considered victims of genocide, the report concluded ISIS did not intend to destroy the Christian community. ${ }^{60}$ The U.N. attributed its decision not to declare genocide of Christians to insufficient persecution that did not suffice the high bar of the Genocide Convention. ${ }^{61}$ The U.N., however, was wrong.

\section{The United Nations' Disregard for Christians}

The international community, specifically the U.N., displayed a alarming reluctance to react appropriate-
$54 \quad I d$.
55 Id. at 18.
56 Id. at 17. See also Matthew Rosenberg, Citing Atrocities, John Kerry Calls ISIS Actions Genocide, New York Times (Mar. 17, 2016). Availa- ble in: https://www.nytimes.com/2016/03/18/world/middleeast/ citing-atrocities-john-kerry-calls-isis-actions-genocide.html?_r $=0$.
57 Nina Shea, ISIS Genocide of Christian Communities in Iraq and Syria, in The Persecution and Genocide of Christians in the Middle East 17, 46 (Ronald J. Rychlak \& Jane F. Adolphe eds., 2017).
58 Id. at 54.
59 Id. at 55.
60 Id.
61 Id. at 55-56. 
ly and within its justifiable force to the ISIS crimes of violence and trafficking against Christians. The tragedies and horrific treatment of women and children by ISIS were acknowledged and condemned throughout the world, but the news media and leaders of countries continually sidestepped the issue of Christianity. While the U.N. was confident to declare genocide by ISIS against the Yazidis, world leaders stopped short of the same designation with regard to Christians - despite the fact the torturous acts happened in the same geography and with the same brutality and tactics. Western media outlets gave sparse attention to the plight of Christians. ${ }^{62}$ Modern-day politics continued to contain pervasiveness on both sides of the aisle to dodge any religious affiliation in an obvious effort to appear secular. ${ }^{63}$ This argument is in no way intended to discount the horrific, unacceptable treatment of the Yazidis by ISIS. Simply, the U.N. shied away from a declaration of genocide by ISIS against Christians, despite the same categorically barbaric, torturous acts employed on the Yazidis. Further, the U.N. commission failed to do a critical analysis of the law, and instead relied on false ISIS propagation. ${ }^{64}$

\subsection{The ISIS Declared-Intent to Destroy Christians and Yazidis}

As part of the 1948 Genocide Convention, the U.N. member states defined genocide in Article II. ${ }^{65}$ While the U.N. asserted that intent is the most difficult of the elements to prove in genocide, the declaration made by ISIS in Dabiq, and the continued threats and brutality against Christians, clearly demonstrated the intent element of the radical group. In Dabiq magazine, the terror group said:

And so we promise you [O crusaders] by Allah's permission that this campaign will be your final campaign. It will be broken and defeated, just as all your previous campaigns were broken and defeated, except that this time we will raid you thereafter, and

62 See generally The Persecution and Genocide of Christians in the Middle East (Ronald J. Rychlak \& Jane F. Adolphe eds., 2017).

63 Human rights activist Nina Shea urged Condoleezza Rice, Secretary of State under George W. Bush, to highlight the persecutions of Christians in the Middle East. Rice's response was, "We can't be sectarian." Al Kresta, Under Caesar's Sword: A Report on the Conference, in The Persecution and Genocide of Christians in the Middle East 363, 366 (Ronald J. Rychlak \& Jane F. Adolphe eds., 2017).

64 Nina Shea, ISIS Genocide of Christian Communities in Iraq and Syria, in The Persecution and Genocide of Christians in the Middle East 17, 55 (Ronald J. Rychlak \& Jane F. Adolphe eds., 2017).

65 U.N. Genocide definition, supra n.13. you will never raid us. We will conquer your Rome, break your crosses, and enslave your women, by the permission of Allah, the Exalted. This is his promise to us; He is glorified and He does not fail in His promise. ${ }^{66}$

The reference to "final campaign" and "never raid us" were certainly evidence of the goal of ISIS to exterminate non-Muslim groups. While the article in Dabiq focused on the Yazidis, the references to "Rome" and "crosses" is undoubtedly directed towards Christians. In 2015, in the seventh issue of Dabiq, ISIS propagated, "the truth is also clear regarding... jihad against the Jews, the Christians ... go forth for jihad and defend your Islam wherever you may be." ${ }^{67}$

The U.N. leaned on the false proposition that the jizya tax or payment was available to Christians, but was not to the Yazidis, which distinguished the two groups. ${ }^{68}$ In actuality, the U.N. willfully chose to fall victim to misleading propaganda from ISIS, more accurately characterized as a "Salafi Caliphate publicity stunt." ${ }^{69}$

By contrast, there is no evidence that ISIS has fulfilled the caliphate's obligations under a jizya agreement. In fact, irrespective of any payment made to it by a Christian, ISIS prevents and punishes Christian worship, attacks the Christian and his family members, and steals the Christian's property. What ISIS refers to as "jizya" taxes are simply extortion and ransom payments that at most provide temporary protection from ISIS attacks. Virtually every Christian who can flees ISIS-controlled territory. The few aged, disabled, and other Christians who have stayed behind in ISIS-controlled areas have been forced to convert to Islam, become jihadi "brides," or been taken captive or killed. In invoking the term jizya, ISIS is providing a pretext to appear more authentically Islamic. Experts on ISIS have called this a "ploy" and a "publicity stunt." Both terms are accurate. ${ }^{70}$

ISIS may have claimed to offer the tax to Christians

66 The Revival of Slaver Before the Hour, Dabiq (2014).

67 Nina Shea, ISIS Genocide of Christian Communities in Iraq and Syria, in The Persecution and Genocide of Christians in the Middle East 17, 54 (Ronald J. Rychlak \& Jane F. Adolphe eds., 2017).

$68 I d$. at 55. "Unlike the Jews and Christians, there was no room for jizyah payment." The Revival of Slaver Before the Hour, Dabiq (2014).

69 Nina Shea, ISIS Genocide of Christian Communities in Iraq and Syria, in The Persecution and Genocide of Christians in the Middle East 17, 55 (Ronald J. Rychlak \& Jane F. Adolphe eds., 2017).

70 Nina Shea, The ISIS Genocide of Middle Eastern Christian Minorities and Its Jisya Propaganda Ploy, Hudson Institute 4 (Aug. 2016). Available in: https://s3.amazonaws.com/media.hudson.org/files/ publications/20160721TheISISGenocideofMiddleEasternChristian MinoritiesandItsJizyaPropagandaPloy.pdf. 
in order to maintain their religious beliefs, but the actual practice or reality of such a possibility was a farce. In September 2014, one family of twelve Assyrian Christians from the town of Nineveh finally escaped after ISIS fighters robbed them and forcibly made them convert to Islam. ${ }^{71}$

The Assyrians said for the first three days they were given food by ISIS but for the next 17 days after they were given nothing. They survived from whatever they had in the house. ISIS stole all their money and their papers. They were brought to an Islamic court in Mosul where they "converted" and were given an Islamic state ID and then returned to Bartella. They said they saw one Assyrian who had not converted and was badly beaten, his hands were tied behind his back and he was driven off in a truck. They assumed that he was killed.72

Ambassador Alberto Fernandez, a former State Department counterterrorism expert, poignantly described ISIS treatment of Christians in Mosul and Nineveh. ${ }^{73}$ "Indeed, there are no images whatsoever of what could be described as normal Christian life in ISIS-controlled territory - no functioning churches, no monasteries or working priests, and no Christian families or Christian schools - all of which had existed throughout Islamic history." 74

\subsection{The Physical Elements and Acts of ISIS Against Non-Muslims}

The second element of genocide, the physical requirements, must be evidenced by five distinguishable acts, which were all exceedingly documented by the destruction and violence of ISIS against the Christians and Yazidis alike. With a brutality and inhumanity of proportions rarely displayed, the terrorists repeatedly broadcasted beheadings of Christians for the world to watch in horror. ${ }^{75}$ Coupled with the countless murders of Christians, nuns, and clergy in the Middle East, ${ }^{76}$

71 Nina Shea, The ISIS Genocide of Middle Eastern Christian Minorities and Its Jizya Propaganda Ploy, Hudson Institute, (Aug., 2016). Available in: https://s3.amazonaws.com/media.hudson.org/files/ publications/20160721TheISISGenocideofMiddleEasternChristian MinoritiesandItsJizyaPropagandaPloy.pdf.

72 Id. at 10.

73 Id. at 11

74 Id. at 13.

75 See supra n.20.

76 See generally The Persecution and Genocide of Christians in the Middle East (Ronald J. Rychlak \& Jane F. Adolphe eds., 2017). without question, the first act of "killing members of the group" could not be disputed. With that comes the forgone conclusion that the second act of "causing serious bodily or mental harm to members of the group" was also evidenced. ISIS demonstrated such brutality against Christians with the forcible rapes of young women and girls witnessed by the victims' family members, which ISIS used to mentally torture and break them into submission. ${ }^{77}$

The third act needed was "deliberately inflicting on the group conditions of life calculated to bring about its physical destruction in whole or in part." In the summer of 2014 during the waves of refugees fleeing Mosul, the ISIS leadership turned off the water supply to some of the Christian places in Nineveh, and explained that they did not deserve to drink. ${ }^{78}$ That, however, was just a small example. The self-proclaimed goal of ISIS was to destroy all Christians, either by death or by conversion to Islam. ${ }^{79}$ There was no middle ground-and no justification for the U.N. not to recognize the intent of ISIS.

ISIS actions abundantly demonstrated the fourth act of "imposing measures intended to prevent births within the group." ISIS fighters separated the men and boys from the women. ${ }^{80}$ With no families intact and the men and women isolated from each other, ISIS prevented the possibility of pregnancies and future generations of Christians. But ISIS also destroyed nearly all

77 Victoria Craw, Inside My Life as an ISIS Sex Slave, New York Post (Oct. 11, 2017). Available in: https://nypost.com/2017/10/11/inside-my-life-as-an-isis-sex-slave/.

78 Nina Shea, The ISIS Genocide of Middle Eastern Christian Minorities and Its Jisya Propaganda Ploy, Hudson Institute 11 (Aug. 2016). Available in: https://s3.amazonaws.com/media.hudson.org/files/ publications/20160721TheISISGenocideofMiddleEasternChristian MinoritiesandItsJizyaPropagandaPloy.pdf.

79 Id.

In one example, a group of men reportedly converted when jihadists threatened to rape the girls.

There was Khalia, a woman in her fifties, who was captured and held hostage along with 47 others. During her 15 days in captivity, she rebuffed demands to convert, despite a gun being put to her head and a sword to her neck. She literally fought off ISIS militants as they tried to rape the girls, and again later when they tried to take a 9-year-old as a bride. Because of the abuse, 14 men gave in to ISIS' demands and said they would convert to Islam. Khalia would not. Ultimately, the hostages were left in the desert to walk to Erbil. Others in Kurdistan affirmed without prompting that 'she had saved many people.'

80 James Reinl, Q\&A: Probing Islamic State's Sex Atrocities with the United Nations, Middle East Eye (May 18, 2015). Available in: http:// www.middleeasteye.net/news/qa-probing-islamic-state-s-sex-atrocities-united-nations-1064004421. 
traces of the group. It essentially performed an ethnic cleansing of Christians in ISIS territories. ${ }^{81}$ Anyone not killed initially was forced to convert from Christianity to Islam, or be murdered. Staying alive and remaining a Christian was not an option, which extinguished any way to sustain Christian populations.

Finally, the fifth of the acts, "forcibly transferring children of the group to another group," was transparent in ISIS actions. ISIS boasted of slaughtering young men and keeping the girls as their sex slaves. Some of those who converted from Christianity remained alive, but only as worshipers of Islam, while all others were murdered. ISIS did not leave any group of Christian children, they either converted to Islam or were murdered-children had no other option.

Arguably, it is impossible to fix a problem the U.N. seemed more willing to downplay. The acts against Christians in the Middle East were appalling, and no less devastating or destructive than those sustained by the Yazidis. ISIS left territories that were once intact, Christian communities without almost anyone from the religious group, and those few who remained had no place to worship and certainly no freedom to do so.

\section{LEGAL OPTIONS TO STOP ISIS AND HUMAN TRAFFICKING}

The only plausible approach of stopping ISIS trafficking and brutality must come from an international approach. While the U.N.'s lackluster stance on ISIS and the treatment of Christians is somewhat of a setback, recent developments are spurring renewed optimism of an ISIS defeat. However, international laws will likely offer little to no accountability of ISIS' crimes.

\subsection{The International Criminal Court}

The International Criminal Court (ICC) developed in 2002 with jurisdiction over individuals who have committed "horrific crimes of an international magnitude." 82 Genocide, war crimes, crimes against hu-

81 See generally Nina Shea, ISIS Genocide of Christian Communities in Iraq and Syria, in The Persecution and Genocide of Christians in the Middle East (Ronald J. Rychlak \& Jane F. Adolphe eds., 2017). 82 Ronald J. Rychlak, Persecution of Christians in the Middle East: The Failed Promise Of the International Criminal Court, in The Persecution manity, and crimes of aggression fall under its jurisdiction, with rape, sexual slavery, and enforced prostitution under the umbrella of crimes against humanity. ${ }^{83}$ Jurisdiction was designed to occur only when a nation is "unwilling or unable" to act. ${ }^{84}$ While the U.N. did not elevate the crimes against Christians to that of genocide, ISIS would still likely escape the reach of the ICC even if it had. ${ }^{85}$

Before they can be held accountable for crimes committed, someone must arrest the members of ISIS and bring them before the court. The arrest is the most difficult part, since the ICC does not have a police force, and must rely on state power. ${ }^{86}$ Even if that difficult piece were accomplished, the ICC only has jurisdiction "if either the 'State on the territory of which' a crime was committed or 'the State of which the person accused of the crime is a national' has ratified the Rome Statute." ${ }^{87}$ However, Syria and Iraq are not parties to the Rome Statute. ${ }^{88}$ While ISIS has recruited several thousand foreign fighters, a "jurisdictional basis for opening a preliminary examination into this situation is too narrow at this stage." 89

ICC Prosecutor Fatou Bensouda issued a statement regarding the reports of ISIS crimes and said they undoubtedly constituted serious crimes of concern to the international community and threatened the peace, security, and wellbeing of the region and the world..$^{90}$ But given the lack of territorial and personal jurisdiction over ISIS, prosecution of ISIS leaders was limited. ${ }^{91}$ Bensouda stressed the primary responsibility for investigation and prosecution of mass crimes rested with re-

and Genocide of Christians in the Middle East 323, 324 (Ronald J. Rychlak \& Jane F. Adolphe eds., 2017).

83 Id.

84 Id. at 325.

85 Id. at 326.

86 Id. at 327.

87 Id. at 329. Former President Bill Clinton signed the Rome Statute of the International Criminal Court on December 31, 2000. Later, President George W. Bush took the unprecedented step of "unsigning" the Rome Statute. As of today, the world's four largest nations, the United States, Russia, China, and India are not parities to the Rome Statute. Id. at 337.

88 Id. at 330.

$89 I d$.

90 Statement of the Prosecutor of the International Criminal Court, Fatou Bensouda, on the alleged crimes committed by ISIS, (Apr. 8, 2015). Available in: https://www.icc-cpi.int/Pages/item. aspx? name $=$ otp-stat-08-04-2015-1.

91 Id. 
levant States. ${ }^{92}$ Therefore, with the ICC virtually powerless to arrest or prosecute ISIS leaders and fighters, accountability falls to the hands of the U.N.

\subsection{The United Nations Security Council}

In September 2017, the U.N. voted 15-0 to launch an investigation in Iraq of the crimes of ISIL (ISIS). ${ }^{93}$ This notion was contemplated previously in 2014, but both Russia and China exercised their veto power to prevent it. ${ }^{94}$ A special advisor appointed by the Secretary-General will lead the investigation team, and consist of both international and domestic experts, with an initial mandate of two years. ${ }^{95}$

\section{Id.}

The International Criminal Court is governed by the Rome Statute, which entrusts the Court with a specific and defined jurisdiction and mandate. A fundamental feature of the Rome Statute (articles 12 and 13) is that the Court may only exercise jurisdiction over international crimes if (i) its jurisdiction has been accepted by the State on the territory of which the crime was committed, (ii) its jurisdiction has been accepted by the State of which the person accused is a national, or (iii) the situation is referred to the Prosecutor by the Security Council acting under Chapter VII of the UN Charter.

The Office of the Prosecutor of the ICC conducts independent and impartial investigations and prosecution of the crimes of genocide, crimes against humanity and war crimes. The Office of the Prosecutor has opened investigations in: Uganda; Democratic Republic of the Congo; Darfur, Sudan; Central African Republic; Kenya; Libya; Côte d'Ivoire and Mali. The Office is also conducting preliminary examinations relating to the situations in Afghanistan, Colombia, Georgia, Guinea, Honduras, Iraq (alleged abuses by UK forces), Nigeria, Palestine and Ukraine. Id.

93 Security Council Approves Probe into ISIL's Alleged War Crimes in Iraq, UN News Centre (Sept. 21, 2017). Available in: http://www. un.org/apps/news/story.asp?NewsID=57631\#.WhYvBbbMy8U.

94 Ronald J. Rychlak, Persecution of Christians in the Middle East: The Failed Promise of the International Criminal Court, in The Persecution and Genocide of Christians in the Middle East 323, 330 (Ronald J. Rychlak \& Jane F. Adolphe eds., 2017). See also U.N. News Centre, Russia, China block Security Council referral of Syria to International Criminal Court, UN News Centre (May 22, 2014). Available in: http:// www.un.org/apps/news/story.asp?NewsID=47860\#.V2gNtLgrKuk. Since 2011, Russia has blocked a U.N. Security Council vote on Syria eight times. See Euan McKirdy, 8 times Russia blocked a UN Security Council resolution on Syria, CNN (Apr. 13, 2017). Available in: http://www.cnn.com/2017/04/13/middleeast/russia-unsc-syriaresolutions/index.html.

95 Security Council Approves Probe into ISIL's Alleged War Crimes in Iraq, UN News Centre (Sept. 21, 2017). Available in: http://www. un.org/apps/news/story.asp?NewsID $=57631$ \#.WhYvBbbMy8U. The resolution stated:

[t]he commission of such acts which may amount to war crimes, crimes against humanity or genocide, is part of the ideology and strategic objectives of ISIL (Da'esh), and used by ISIL (Da'esh) as a tactic of terrorism, and that holding ISIL (Da'esh) members accountable, particularly those who bear the greatest responsibility,
Amal Clooney, a human rights attorney and counsel for Yazidi survivors has urged the U.N. to take action for more than a year. ${ }^{96}$ "The resolution is a rare show of unity for the council and provides a global response to ISIS that extends beyond the battlefield to include a commitment to punishing individuals through the courts." ${ }^{97}$ Clooney's efforts are targeted at securing justice for survivors, and putting ISIS on trial. On March 8, 2017, Clooney told the U.N. representatives, "[m]y message to you was that ISIS is a global threat, which requires a global response, and that the response should not be limited to the battlefield: the U.N. should also investigate ISIS' crimes and make sure that those responsible are brought to justice." ${ }^{\prime 98}$

While an investigation into ISIS war crimes and genocide in Iraq will analyze the terror groups' actions from a reflective view, other efforts are still necessary to stop the proliferation of ISIS brutality in the Middle East.

\subsection{Continued United States and Allied Military Action Against ISIS}

Future violence and brutality of ISIS can only be prevented by permanently dismantling the group. In August 2017, U.S. President Donald Trump moved forward with a long-awaited strategy for resolving the conflict in the Middle East. ${ }^{99}$ The U.S. is deploying more American troops to Afghanistan after concerns of a deteriorating security situation for the Afghan forces. ${ }^{100}$ U.S. Defense Secretary James Mattis announced

including in terms of leadership, which can include regional or midlevel commanders, and the ordering and commission of crimes, will further expose this, and could assist in countering terrorism and violent extremism which can be conducive to terrorism, including by stemming financing and the continued flow of international recruits to the terrorist group ISIL (Da'esh). Id.

96 Madison Rossi, Amal Clooney Praises United Nations for Putting ISIS Terrorists 'On Trial' Via New International Investigation, People (Sept. 25, 2017). Available in: http://people.com/movies/amalclooney-praises-united-nations-for-putting-isis-terrorists-on-trialvia-new-international-investigation/.

97 Id.

98 Id.

99 David Nakamura \&Abby Phillip, Trump Announces New Strategy for Afghanistan that Calls for a Troop Increase, The Washington Post (Aug. 21, 2017). Available in: https://www.washingtonpost.com/ politics/trump-expected-to-announce-small-troop-increase-inafghanistan-in-prime-time-address/2017/08/21/eb3a513e-868a11e7-a94f-3139abce39f5_story.html?utm_term=.0ee1669194d5. 100 Id. 
the pivot to "annihilation tactics" instead of attrition, to defeat ISIS. ${ }^{101}$ "Our intention is that the foreign fighters do not survive the fight to return home to North Africa, to Europe, to America, to Asia, to Africa. We are not going to allow them to do so. We are going to stop them there and take apart the caliphate."102

Shortly thereafter, in October of 2017, U.S.-backed forces regained control in Raqqa, the self-declared capital of ISIS. ${ }^{103}$ Director of the Syrian Observatory for Human Rights (SOHR), Rami Abdelrahman, said that "only a few, dozens of fighters from ISIS, are still in the centre of the city ... The rest are killed. That's it. Finished. Game over." 104

Despite the loss of ISIS-held territory, the slave trade continues to prosper. ${ }^{105}$ ISIS still holds more than 3,000 people, mostly women and children, according to the Kurdistan Regional Government's (KRG) Office of Kidnapped Rescues. ${ }^{106}$ Military leaders fighting against ISIS speculate where the remaining ISIS soldiers will settle. ${ }^{107}$ The number of ISIS fighters in Afghanistan poses serious security concerns for Russia, estimated at about 2,500 ISIS combatants, with the group planning to expand. ${ }^{108}$ The Special Inspector General for Afgha-

101 Kathryn Watson, Fight Against ISIS has Shifted to "Annibilation Tactics," Mattis says CBS News (May 28, 2017). Available in: https:/ / www.cbsnews.com/news/fight-against-isis-has-shifted-to-annihilation-tactics-mattis-says/.

102 Id.

103 See supra n.10.

104 Dr. Ely Karmon, The Day After ISIS: the Middle East After the Islamic State Where Will ISIS Regroup?, BICOM (Oct. 10, 2017). Available in: http://www.bicom.org.uk/blogpost/day-isis-middleeast-islamic-state-will-isis-regroup/.

105 See supra n.11.

106 Id.

107 Dr. Ely Karmon, The Day After ISIS: the Middle East After the Islamic State Where Will ISIS Regroup?, BICOM (Oct. 10, 2017). Available in: http://www.bicom.org.uk/blogpost/day-isis-middleeast-islamic-state-will-isis-regroup/.

After the demise of ISIS and the destruction of the Caliphate as a territorial entity, many foreign fighters, especially those from the Caucasus as well as central and southeast Asia will either return home or more likely will turn to Taliban "liberated" territory in Afghanistan and the Pakistan tribal areas, a sort of revival of the 1990s situation. They may try to build an ISIS territorial base there but many could instead strengthen the ranks of al-Qaeda in the region because its ally, the Taliban, has succeeded in weakening the proISIS groups that tried to challenge it in the region. Id.

108 Id.

Contrary to optimistic predictions, ISIS has been expanding its presence in Afghanistan to at least five provinces, from Nangarhar, Kunar, and Nuristan in the east to Jawzjan in the north and Ghor in the west. It is neither a monolithic group nor a direct extension of the group in Iraq and Syria, rather an alliance of splinter groups nistan Reconstruction (SIGAR) said sixty percent of Afghanistan's districts are under government control, with the remaining forty percent held by the Taliban or other armed groups. ${ }^{109}$

\subsection{The Impact of National Trafficking Laws}

The U.N. completed a study in 2016 on the global trafficking of persons. The study found that from 2003 to 2016, the number of statutes criminalizing forms of human trafficking increased from thirty-three countries to $158 .{ }^{110}$ Most of the legislation has been introduced within the last eight to ten years, and the average number of convictions is still low. Statistics show the longer countries have comprehensive legislation in place, the more convictions they record. ${ }^{111}$

In 2000, the U.S. passed the first federal law aimed at human trafficking, the Trafficking Victims Protection Act (TVPA) of $2000 .{ }^{112}$ It addressed trafficking with a three-prong approach that included prevention, protection, and prosecution. Under U.S. federal law, severe forms of trafficking in persons included both sex trafficking ${ }^{113}$ and labor trafficking. ${ }^{14}$ In 2003 , the legisla-

from the Afghan and Pakistani Taliban with elements of regional militant groups such as IMU and the Pakistan-based Lashkare Jhangvi. There is little evidence yet of fighters relocating from Iraq and Syria in large numbers, although Afghan Defense Ministry spokesman General Dawlat Waziri stated in August that the government had observed an increase in numbers of foreign fighters and weapons entering the country. Id.

109 Id.

110 Global Report on Trafficking in Persons 2016, United Nations Office on Drugs and Crime (2016). Available in: http://www.unodc. org/documents/data-and-analysis/glotip/2016_Global_Report_ on_Trafficking_in_Persons.pdf.

111 Id. The report concluded that it takes time and dedicated resources for a national criminal justice system to acquire sufficient expertise to detect, investigate, and successfully prosecute cases of trafficking in persons. $I d$.

112 Victims of Trafficking and Violence Protection Act of 2000, H.R. 3244, 106th Cong. (2000). https://www.state.gov/j/tip/ laws/61124.htm (October 28, 2000). The TVPA was reauthorized through the Trafficking Victims Protection Reauthorization Act (TVPRA) of 2003, 2005, 2008, and 2013.

113 Sex trafficking is the recruitment, harboring, transportation, provision, obtaining, patronizing, or soliciting of a person for the purposes of a commercial sex act, in which the commercial sex act is induced by force, fraud, or coercion, or in which the person induced to perform such an act has not attained 18 years of age. 22 USC $\int$ 7102 (2000).

114 Labor trafficking is the recruitment, harboring, transportation, provision, or obtaining of a person for labor or services, through the use of force, fraud, or coercion for the purposes of subjection to involuntary servitude, peonage, debt bondage, or slav- 
ture enhanced the punishment of individuals engaged in sex tourism with children from the U.S. and other countries. ${ }^{115}$ In 2015, the legislature enacted the Justice for Victims of Trafficking Act (JVTA) of 2015, which made the criminal liability of buyers equal to that of sellers of commercial sex. ${ }^{116}$ It also led to the creation of a survivor-led U.S. advisory council on human trafficking, and new directives for the implementation of a national strategy for combating human trafficking. ${ }^{117}$

Another tool at the hands of U.S. federal prosecutors in trafficking cases is the Racketeer Influenced and Corrupt Organization Act (RICO). Since 2003, federal prosecutors have been able to charge human and sex traffickers under the RICO Act. ${ }^{118}$ The first case though

ery. 22 USC S 7102 (2000).

115 PROTECT Act, S. 151, 108th Cong. (2003-2004) (enacted). See also The PROTECT Act, Polaris, https://polarisproject.org/currentfederal-laws. It also created the Amber Alert System and other methods of alerting the public to missing, exploited, and abducted children; and grants for transitional housing for child victims of sexual assault. S. 151, 108th Congress $\ 301-305$ (2003-2004); Expanded the prohibitions on, and increases penalties for, traveling in or into the United States or in foreign commerce to engage in illicit sexual conduct, $\mathrm{S}$. 151. $\int 105$; Considered a defendant to have engaged in a pattern of activity involving prohibited sexual conduct if, on at least two separate occasions, such defendant engaged in such conduct with a minor, (S. 151. \401; Provided for specified offense level increases if the offense involved: (1) material that portrays sadistic or masochistic conduct or other depictions of violence (up four levels); and (2) specified numbers of images (up from two to five levels). S. 151. \ 401.

116 Justice for Victims of Trafficking Act of 2015, S. 178, 114th Cong. \ 108 (2015-2016).

This section requires DOJ to ensure that each DOJ anti-human trafficking program includes technical training on: (1) effective methods for investigating and prosecuting persons who obtain, patronize, or solicit commercial sex acts involving a person subject to severe forms of trafficking in persons (buyers); and (2) facilitating the provision of physical and mental health services to persons subject to severe forms of trafficking in persons. The Bureau of Justice Statistics of DOJ is required to prepare and submit annual reports on state enforcement of human trafficking prohibitions.

Justice for Victims of Trafficking Act of 2015, S. 178, 114th Cong. \ 114 (2015-2016).

117 Justice for Victims of Trafficking Act of 2015, S. 178, 114th Cong. $\int 115$ (2015-2016).

118 109. RICO Charges, United States Department of Justice. Available in: https://www.justice.gov/usam/criminal-resourcemanual-109-rico-charges.

It is unlawful for anyone employed by or associated with any enterprise engaged in, or the activities of which affect, interstate or foreign commerce, to conduct or participate, directly or indirectly, in the conduct of such enterprise's affairs through a pattern of racketeering activity or collection of unlawful debt. 18 U.S.C. \$ 1962 (c). A more expansive view holds that in order to be found guilty of violating the RICO statute, the government must prove beyond a reasonable doubt: (1) that an enterprise existed; (2) that the enterprise affected interstate commerce; (3) that the defendant was associated was not brought until 2009 in the Western District of Missouri. ${ }^{119}$

Even with more than seventeen years of evolving human trafficking laws in the U.S, justice is still amiss. The legislature defines and criminalizes trafficking, and equalizes purchasers and sellers of humans, which are effective police and prosecution tools domestically. ${ }^{120}$ But without a way to assert jurisdiction, these laws have little to no significance in addressing the genocide of Christians in Syria or Iraq. Even if ISIS terrorists did engage in the acts on U.S. soil or against Americans, the laws are only as effective as the U.S.'s ability to capture and prosecute terrorists.

In 2016, the House of Representatives unanimously adopted the first draft of the genocide resolution. ${ }^{121}$ This move was a solid first step towards long-term legislative and appropriations measures with substantial political and fiscal consequences domestically and abroad. ${ }^{122}$ In order to prevent and punish the horrific

with or employed by the enterprise; (4) that the defendant engaged in a pattern of racketeering activity; and (5) that the defendant conducted or participated in the conduct of the enterprise through that pattern of racketeering activity through the commission of at least two acts of racketeering activity as set forth in the indictment. Id.

119 Eight Uzbekistan Nationals Among 12 Charged with Racketeering, Human Trafficking \& Immigration Violations in Scheme to Employ Illegal Aliens in 14 States, The United States Department of Justice (May 27, 2009). Available in: https://www.justice.gov/ $\mathrm{opa} / \mathrm{pr} /$ eight-uzbekistan-nationals-among-12-charged-racketeering-human-trafficking-immigration.

120 Justice for Victims of Trafficking Act of 2015, S. 178, 114th Cong. $\$ 114$ (2015-2016).

121 H.R. Con. Res. 75, 114th Cong. (2015-2016). Expressing the sense of Congress that the atrocities perpetrated by ISIL against religious and ethnic minorities in Iraq and Syria include war crimes, crimes against humanity, and genocide.

[t] he atrocities perpetrated by the Islamic State of Iraq and the Levant (ISIL) against Christians, Yezidis, and other religious and ethnic minorities in Iraq and Syria constitute war crimes, crimes against humanity, and genocide; all governments, including the United States, and international organizations, including the United Nations (U.N.), should call ISIL atrocities war crimes, crimes against humanity, and genocide; U.N. member states should coordinate on measures to prevent further war crimes, crimes against humanity, and genocide in Iraq and Syria, and to punish those responsible for these ongoing crimes, including by the collection of evidence and, if necessary, the establishment of appropriate tribunals; the Hashemite Kingdom of Jordan, the Lebanese Republic, the Republic of Turkey, and the Kurdistan Regional Government in Iraq are to be commended for, and supported in, their efforts to shelter those fleeing violence from ISIL and other combatants until they can safely return to their homes in Iraq and Syria; and the protracted Syrian civil war and the indiscriminate violence of the Assad regime have contributed to ISIL's growth. Id.

122 Robert A. Destro, Genocide, Statecraft, and Domestic Geopolitics, in 
brutality of ISIS, the U.S. must start with such a resolution as a basis for future decisions and policies.

\section{Final Considerations}

The U.N.'s selective declaration of genocide is unfortunate, and will not accelerate accountability of ISIS for actions against Christians. The declaration is critical, because it carries with it the international political footing necessary to motivate changes in policy. The refusal of the U.N. to critically analyze the persecution of Christians highlights the international hesitancy to validate Christianity.

Given the difficulty of capturing ISIS fighters and leaders, combined with the challenges of prosecution, the most effective way of ending the ISIS terror against Yazidis and Christians is through a military defeat and total elimination of the group. Present-day challenges for trafficking victims are no longer a consequence of absent good laws. Instead, the present-day challenge centers on the lack of enforcement capacity. Trafficking laws cannot be carried out if police, prosecutors, and judges are not equipped with the skills and tools to execute. $^{123}$

Moving forward, the global community should proceed with cautious optimism. Recent victories should not give way to a false sense of security or disproportionate measure of success against ISIS. Even if the terrorist group falls, the U.S. and other nations must be ready to navigate safety in politically unstable regions with others eager to target Christians and other minority groups. As the U.N. investigates the genocide of Yazidis and the war crimes of ISIS, it should also evaluate the crimes of ISIS against Christians, and elevate its designation to genocide. Yet even without the declaration, the international community needs to rally behind all groups subject to terrorism, just as it has the Yazidis. Christianity should not be an impediment to justice.

The Persecution and Genocide of Christians in the Middle East 59, 89 (Ronald J. Rychlak \& Jane F. Adolphe eds., 2017).

123 Victor Boutros \& John Richmond, The World Day Against Trafficking Persons, Oxford Human Rights Hub (Sept. 11, 2017). Available in: http://ohrh.law.ox.ac.uk/the-world-day-against-traffickingin-persons/.

\section{References}

109. RICO Charges, United States Department of Justice. Available in: https://www.justice.gov/usam/criminal-resource-manual-109-rico-charges

22 USC \ 7102 (2000)

Al Kresta, Under Caesar's Sword: A Report on the Conference, in The Persecution and Genocide of Christians in the Middle East 363, 366 (Ronald J. Rychlak \& Jane F. Adolphe eds., 2017)

Allen McDuffee, ISIS Is Now Bragging About Enslaving Women and Children, The Atlantic Daily (Oct. 13, 2014). Available in: https://www.theatlantic.com/international/archive/2014/10/isis-confirms-and-justifies-enslaving-yazidis-in-new-magazine-article/381394/

Andrew Cockburn, 21st-Century Slaves, National Geographic, (Sept. 2003)

Cathy Otten, Life After ISIS Slavery for Yazidi Women and Children, The New Yorker (Aug. 31, 2017). Available in: https://www.newyorker.com/news/news-desk/lifeafter-isis-slavery-for-yazidi-women-and-children

CNN Library, ISIS Fast Facts, CNN (Updated Oct. 17, 2017), http://www.cnn.com/2014/08/08/world/isisfast-facts/index.html

David Nakamura \&Abby Phillip, Trump Announces New Strategy for Afghanistan that Calls for a Troop Increase, The Washington Post (Aug. 21, 2017). Available in: https://www.washingtonpost.com/politics/ trump-expected-to-announce-small-troop-increasein-afghanistan-in-prime-time-address/2017/08/21/ eb3a513e-868a-11e7-a94f-3139abce39f5_story. html?utm_term $=.0 e e 1669194 \mathrm{~d} 5$

Dr. Ely Karmon, The Day After ISIS: the Middle East After the Islamic State Where Will ISIS Regroup?, BICOM (Oct. 10, 2017). Available in: http://www.bicom.org. uk/blogpost/day-isis-middle-east-islamic-state-willisis-regroup/

Eight Uzbekistan Nationals Among 12 Charged with Racketeering, Human Trafficking \& Immigration Violations in Scheme to Employ Illegal Aliens in 14 States, The United States Department of Justice (May 27, 2009). Available in: https://www.justice.gov/opa/pr/eight-uzbekistannationals-among-12-charged-racketeering-human-trafficking-immigration 
End Trafficking, UNICEF. Available in: https://www. unicefusa.org/sites/default/files/assets/pdf/EndChild-Trafficking-One-Pager.pdf

Euan McKirdy, 8 times Russia blocked a UN Security Council resolution on Syria, CNN (Apr. 13, 2017). Available in: http://www.cnn.com/2017/04/13/middleeast/russiaunsc-syria-resolutions/index.html

Faisal Irshaid, Isis, Isil, IS or Daesh? One Group, Many Names, BBC (Dec, 2, 2015). Available in: http://www.bbc. com/news/world-middle-east-27994277

Global Report on Trafficking in Persons 2016, United Nations Office on Drugs and Crime (2016). Available in: http://www.unodc.org/documents/data-and-analysis/ glotip/2016_Global_Report_on_Trafficking_in_Persons.pdf

H.R. Con. Res. 75, 114th Cong. (2015-2016)

Hilary Clarke, Nick Paton Walsh, Eliza Mackintosh \& Ghazi Balkiz, ISIS Defeated in Raqqa as Major Military Operations' Declared Over, CNN (Oct. 18, 2917). Available in: http://www.cnn.com/2017/10/17/middleeast/ raqqa-isis-syria/index.html

Hudson Institute Releases Report on the ISIS Propaganda Ploy to Hide its Genocide of Christians, Hudson Institute (July 21, 2016), Available in: https://www.hudson.org/ research/12666-hudson-institute-releases-report-onthe-isis-propaganda-ploy-to-hide-its-genocide-of-christians

Ishaan Tharoor, Islamic State Burned a Woman Alive for not Engaging in an 'Extreme' Sex Act, U.N. Official Says, The Washington Post (May 22, 2015). Available in: https://www.washingtonpost.com/news/worldviews/ wp/2015/05/22/islamic-state-burned-a-woman-alivefor-not-engaging-in-an-extreme-sex-act-u-n-officialsays/?utm_term $=.4058 \mathrm{e} 0 \mathrm{a} 57 \mathrm{e} 79$

Jack Moore, ISIS Leader Abu Baker Al-Baghdadi is Likely Alive, U.S. Commander Says, Newsweek (Sept. 1, 2017). Available in: http://www.newsweek.com/intelligencepoints-isis-leader-abu-bakr-al-baghdadi-being-alive-uscommander-658192

James Reinl, Q\&A: Probing Islamic State's Sex Atrocities with the United Nations, Middle East Eye (May 18, 2015). Available in: http://www.middleeasteye.net/news/ qa-probing-islamic-state-s-sex-atrocities-united-nations-106400442

Jim Acosta \& Jeremy Diamond, Obama ISIS Fight Re- quest Sent to Congress, CNN (February 12, 2015). Available in: http://www.cnn.com/2015/02/11/politics/ isis-aumf-white-house-congress/index.html

Justice for Victims of Trafficking Act of 2015, S. 178, 114th Cong. (2015-2016)

Kathryn Watson, Fight Against ISIS has Shifted to "Annibilation Tactics," Mattis says CBS News (May 28, 2017). Available in: https://www.cbsnews.com/news/fightagainst-isis-has-shifted-to-annihilation-tactics-mattissays/

Letter from President Barack Obama to The Congress of the United States (Feb. 11,2015). Available in: http://i2.cdn.turner.com/cnn/2015/ images/02/11/2015aumf.2.11.15.msg.rel.pdf

Loretta Napoleoni, Merchants of Men: How Jihadists and ISIS Turned Kidnapping and Refugee Trafficking into a Multi-Billion Dollar Business (2016)

Madison Rossi, Amal Clooney Praises United Nations for Putting ISIS Terrorists 'On Trial' Via New International Investigation, People (Sept. 25, 2017). Available in: http:// people.com/movies/amal-clooney-praises-united-nations-for-putting-isis-terrorists-on-trial-via-new-international-investigation/

Mark J. Perry, Thomas Sowell on Slavery and This Fact There are More Slaves Today Than Were Seized From Africa in Four Centuries, AEIdeas (October 18, 2017). Available in: http://www.aei.org/publication/thomas-sowell-onslavery-and-this-fact-there-are-more-slaves-today-thanwere-seized-from-africa-in-four-centuries/

Matthew Rosenberg, Citing Atrocities, John Kerry Calls ISIS Actions Genocide, New York Times (Mar. 17, 2016). Available in: https://www.nytimes.com/2016/03/18/ world/middleeast/citing-atrocities-john-kerry-callsisis-actions-genocide.html?_r $=0$

Melissa L. Breger, Trauma in Sex-Trafficked Children, in Human Trafficking, Emerging Legal Issues and Applications, 171, 172 (Nora M. Cronin \& Kimberly A. Ellis eds., 2017)

Nick Vivion, Human Trafficking: Toppling a \$32 Billion Illegal Industry through Technology, Sabre (May 25, 2016). Available in: https://www.sabre.com/insights/humantrafficking-toppling-a-32-billion-illegal-industry-through-technology/

Nima Elbagir, Ghazi Balkiz, \& Tamara Qiblawi, ISIS' Power is Waning, but its Child Slave Trade is Still Booming, 
CNN (Oct. 18, 2017). Available in: http://www.cnn. com/2017/10/18/middleeast/isis-yazidi-slavery-childslaves/index.html

Nina Shea, The ISIS Genocide of Middle Eastern Christian Minorities and Its Jisya Propaganda Ploy, Hudson Institute (Aug., 2016). Available in: https://s3.amazonaws.com/ media.hudson.org/files/publications/20160721TheISISGenocideofMiddleEasternChristianMinoritiesandIts JizyaPropagandaPloy.pdf

Nina Shea, The ISIS Genocide of Middle Eastern Christian Minorities and Its Jizya Propaganda Ploy Hudson Institute (Jul. 21, 2016). Available in: https://www.hudson.org/ research/12665-the-isis-genocide-of-middle-easternchristian-minorities-and-its-jizya-propaganda-ploy

Pope Francis, Christianity Threatened in ISIS Propaganda Video that Vatican Aide Calls Worrying, Fox News (Aug. 26, 2017). Available in: http://www.foxnews.com/ world/2017/08/26/pope-francis-christianity-threatened-in-isis-propaganda-video.html

PROTECT Act, S. 151, 108th Cong. (2003-2004) (enacted)

Ray Sanchez, ISIL, ISIS or the Islamic State?, CNN (Oct. 25, 2017). Available in: http://www.cnn. com/2014/09/09/world/meast/isis-isil-islamic-state/

Rex W. Tillerson, Secretary of State, Letter from Secretary Tillerson, Trafficking in Persons Report 2017. Available in: https://www.state.gov/j/tip/rls/tiprpt/2017/271105. $\mathrm{htm}$

Security Council Approves Probe into ISIL's Alleged War Crimes in Iraq, UN News Centre (Sept. 21, 2017). Available in: http://www.un.org/apps/news/story. asp?NewsID=57631\#.WhYvBbbMy8U

Shannon A. Welch, Note, Human Trafficking and Terrorism: Utilizing National Security Resources to Prevent Human Trafficking in the Islamic State, 24 Duke J. Gender L. \& Pol'y, 165, 169 (2017)
Statement of the Prosecutor of the International Criminal Court, Fatou Bensouda, on the alleged crimes committed by ISIS, (Apr. 8, 2015). Available in: https://www.icc-cpi.int/Pages/item.aspx?name=otpstat-08-04-2015-1

Stephen J. Schulhofer, The Enemy Within (2002)

Terrorists use Human Trafficking to Generate Revenue, Demoralize Adversaries, Fill the Ranks, Lexis-Nexus (Dec. 31, 2014). Available in: http://www.homelandsecuritynewswire.com/dr20141231-terrorists-use-human-trafficking-to-generate-revenue-demoralize-adversaries-fillthe-ranks

The Persecution and Genocide of Christians in the Middle East (Ronald J. Rychlak \& Jane F. Adolphe eds., 2017)

The PROTECT Act, Polaris. Available in: https://polarisproject.org/current-federal-laws

The Revival of Slaver Before the Hour, Dabiq (2014)

Trafficking and Terrorism, Partners in Crime, The Freedom Story (June 29, 2017). Available in: http://thefreedomstory.org/trafficking-and-terrorism-partners-incrime

U.N. News Centre, Russia, China block Security Council referral of Syria to International Criminal Court, UN News Centre (May 22, 2014). Available in: http://www.un.org/apps/ news $/$ story.asp?NewsID $=47860 \# . V 2 g N t L g r K u k$

United Nations Genocide Prevention and the Responsibility to Protect, United Nations. Available in: http://www. un.org/en/genocideprevention/genocide.html

Victims of Trafficking and Violence Protection Act of 2000, H.R. 3244, 106th Cong. (2000). Available in: https://www.state.gov/j/tip/laws/61124.htm (October 28, 2000)

Victor Boutros \& John Richmond, The World Day Against Trafficking Persons, Oxford Human Rights Hub (Sept. 11, 2017) Available in: http:/ /ohrh.law.ox.ac.uk/ the-world-day-against-trafficking-in-persons/

Victoria Craw, Inside My Life as an ISIS Sex Slave, New York Post (Oct. 11, 2017). Available in: https://nypost. com/2017/10/11/inside-my-life-as-an-isis-sex-slave/ 
Para publicar na Revista de Direito Internacional, acesse o endereço eletrônico www.rdi.uniceub.br ou www.brazilianjournal.org.

Observe as normas de publicação, para facilitar e agilizar o trabalho de edição. 